\title{
ASYMPTOTICALLY QUASI-NONEXPANSIVE MAPPINGS WITH RESPECT TO THE BREGMAN DISTANCE IN THE INTERMEDIATE SENSE
}

\author{
YUKINO TOMIZAWA \\ Department of Mathematics, Faculty of Science and Engineering, Chuo University \\ 1-13-27 Kasuga, Bunkyo-ku, Tokyo 112-8551, Japan \\ E-mail: tomizawa@gug.math.chuo-u.ac.jp
}

\begin{abstract}
The purpose of this paper is to introduce a new class of nonlinear mappings which is an extension of asymptotically quasi-nonexpansive mappings with respect to the Bregman distance in the intermediate sense. A strong convergence theorem of the shrinking projection method with the modified Mann iteration is established to find fixed points of the mappings in reflexive Banach spaces.
\end{abstract}

Key Words and Phrases: Bregman distance, Bregman projection, asymptotically quasinonexpansive in the intermediate sense, fixed point, Legendre function, totally convex function.

2010 Mathematics Subject Classification: 26B25, 46T99, 47H09, 47H10, 47J25.

\section{REFERENCES}

[1] Y.I. Alber, Metric and generalized projection operators in Banach spaces: properties and applications, Theory and Applications of Nonlinear Operators of Accretive and Monotone Type, Lecture Notes Pure Appl. Math., 178, Dekker, New York, 1996, 15-50.

[2] V. Barbu, Nonlinear Differential Equations of Monotone Types in Banach Spaces, Springer, New York, 2010.

[3] H.H. Bauschke, J.M. Borwein, P.L. Combettes, Essential smoothness, essential strict convexity, and Legendre functions in Banach spaces, Commun. Contemp. Math., 3(2001), no. 4, 615-647.

[4] H.H. Bauschke, M.S. Macklem, X. Wang, Chebyshev sets, Klee sets, and Chebyshev centers with respect to Bregman distances: recent results and open problems, Fixed-Point Algorithms for Inverse Problems in Science and Engineering, Springer, Optim. Appl., 49, Springer, New York, 2011, 1-21.

[5] H.H. Bauschke, X. Wang, J. Ye, X. Yuan, Bregman distances and Chebyshev sets, J. Approx. Theory, 159(2009), no. 1, 3-25.

[6] J.M. Borwein, Q.J. Zhu, Multifunctional and functional analytic techniques in nonsmooth analysis, Nonlinear Analysis, Differential Equations and Control, NATO Sci. Ser. C Math. Phys. Sci., 528, Kluwer Acad. Publ., Dordrecht, 1999, 61-157.

[7] L.M. Bregman, The relaxation method of finding the common point of convex sets and its application to the solution of problems in convex programming, USSR Comput. Math. Math. Phys., 7(1967), no. 3, 200-217.

[8] R.E. Bruck, T. Kuczumow, S. Reich, Convergence of iterates of asymptotically nonexpansive mappings in Banach spaces with the uniform Opial property, Colloq. Math., 65(1993), no. 2, 169-179. 
[9] D. Butnariu, Y. Censor, S. Reich, Iterative averaging of entropic projections for solving stochastic convex feasibility problems, Comput. Optim. Appl., 8(1997), no. 1, 21-39.

[10] D. Butnariu, A.N. Iusem, Totally Convex Functions for Fixed Points Computation and Infinite Dimensional Optimization, Kluwer Academic Publ., Dordrecht, 2000.

[11] D. Butnariu, A.N. Iusem, C. Zălinescu, On uniform convexity, total convexity and convergence of the proximal point and outer Bregman projection algorithms in Banach spaces, J. Convex Anal., 10(2003), no. 1, 35-61.

[12] D. Butnariu, E. Resmerita, Bregman distances, totally convex functions, and a method for solving operator equations in Banach spaces, Abstr. Appl. Anal., (2006), 1-39.

[13] D. Butnariu, S. Reich, A.J. Zaslavski, There are many totally convex functions, J. Convex Anal., 13(2006), 623-632.

[14] Y. Censor, A. Lent, An iterative row-action method for interval convex programming, J. Optim. Theory Appl., 34(1981), no. 3, 321-353.

[15] K. Goebel, W.A. Kirk, A fixed point theorem for asymptotically nonexpansive mappings, Proc. Amer. Math. Soc., 35(1972), 171-174.

[16] K. Goebel, S. Reich, Uniform Convexity, Hyperbolic Geometry, and Nonexpansive Mappings, M. Dekker, New York, 1984.

[17] Y. Hao, Some results on a modified Mann iterative scheme in a reflexive Banach space, Fixed Point Theory Appl., (2013), 2013:227, 14 pp.

[18] Y. Hecai, L. Aichao, Projection algorithms for treating asymptotically quasi- $\phi$-nonexpansive mappings in the intermediate sense, J. Inequal. Appl., (2013), 2013:265, 15 pp.

[19] T. Ibaraki, W. Takahashi, A new projection and convergence theorems for the projections in Banach spaces, J. Approx. Theory, 149(2007), no. 1, 1-14.

[20] I. Inchan, Strong convergence theorems of modified Mann iteration methods for asymptotically nonexpansive mappings in Hilbert spaces, Int. J. Math. Anal., 2(2008), no. 23, 1135-1145.

[21] F. Kohsaka, W. Takahashi, Generalized nonexpansive retractions and a proximal-type algorithm in Banach spaces, J. Nonlinear Convex Anal., 8(2007), no. 2, 197-209.

[22] V. Martín-Márquez, S. Reich, S. Sabach, Iterative methods for approximating fixed points of Bregman nonexpansive operators, Discrete Contin. Dyn. Syst. Ser. S, 6(2013), no. 4, 1043-1063.

[23] V. Martín-Márquez, S. Reich, S. Sabach, Right Bregman nonexpansive operators in Banach spaces, Nonlinear Anal., 75(2012), no. 14, 5448-5465.

[24] U. Mosco, Convergence of convex sets and of solutions of variational inequalities, Adv. Math., 3(1969), 510-585.

[25] R.R. Phelps, Convex Functions, Monotone Operators, and Differentiability, Second ed., Lecture Notes in Math., vol. 1364, Springer-Verlag, Berlin, 1993.

[26] Y. Qing, Some results on asymptotically quasi- $\phi$-nonexpansive mappings in the intermediate sense, J. Fixed Point Theory, (2012), 2012:1, 15pp.

[27] S. Reich, Asymptotic behavior of contractions in Banach spaces, J. Math. Anal. Appl., 44(1973), 57-70.

28] S. Reich, A weak convergence theorem for the alternating method with Bregman distances, Theory and Applications of Nonlinear Operators of Accretive and Monotone Type, Lecture Notes Pure Appl. Math., 178, Dekker, New York, 1996, 313-318.

[29] S. Reich, S. Sabach, Two strong convergence theorems for a proximal method in reflexive Banach spaces, Numer. Funct. Anal. Optim., 31(2010), no. 1, 22-44.

[30] S. Reich, S. Sabach, Two strong convergence theorems for Bregman strongly nonexpansive operators in reflexive Banach spaces, Nonlinear Anal., 73(2010), no. 1, 122-135.

[31] S. Reich, S. Sabach, Existence and approximation of fixed points of Bregman firmly nonexpansive mappings in reflexive Banach spaces, Fixed-Point Algorithms for Inverse Problems in Science and Engineering, Springer, Optim. Appl., 49, Springer, New York, 2011, 301-316.

[32] S. Reich, S. Sabach, A projection method for solving nonlinear problems in reflexive Banach spaces, J. Fixed Point Theory Appl., 9(2011), 101-116.

[33] E. Resmerita, On total convexity, Bregman projections and stability in Banach spaces, J. Convex Anal., 11(2004), no. 1, 1-16. 
[34] J. Schu, Weak and strong convergence to fixed points of asymptotically nonexpansive mappings, Bull. Austral. Math. Soc., 43(1991), no. 1, 153-159.

[35] S. Suantai, Y.J. Cho, P. Cholamjiak, Halpern's Iteration for Bregman strongly nonexpansive mappings in reflexive Banach spaces, Comput. Math. Appl., 64(2012), 489-499.

[36] W. Takahashi, Nonlinear Functional Analysis, Yokohama Publishers, Yokohama, 2000.

[37] W. Takahashi, Y. Takeuchi, R. Kubota, Strong convergence theorems by hybrid methods for families of nonexpansive mappings in Hilbert spaces, J. Math. Anal. Appl., 341(2008), no. 1, 276-286.

[38] W. Takahashi, J.-C. Yao, Weak and strong convergence theorems for positively homogeneous nonexpansive mappings in Banach spaces, Taiwanese J. Math., 15(2011), no. 3, 961-980.

Received: April 24, 2014; Accepted: February 28, 2015. 
